\title{
PERTENTANGAN IMPLEMENTASI ATURAN KONSTITUSI DAN SYARI'AH \\ DARI PUTUSAN UJI MATERI MAHKAMAH KONSTITUSI PADA UU PERKAWINAN NOMOR 1 TAHUN 1974 PASAL 43 AYAT 1
}

\author{
Begum Fauziyah \\ Jurusan Kimia Fakultas Sains dan Teknologi UIN Maliki Malang \\ Email : bee_fauzia@yahoo.co.id \\ Telepon: 081939149233
}

\section{Abstract}

The discretion of constitutional court to issue material test on marital law Number I/1974 verse 43 on unmarried -born child to get law protection causes a debate among societies particularly among muslim societies. With this consideration, this constitution emphasizes that there is a civil law relationship between the child and his or her biologic father if it can be proven. As a result of the new regulation on this issue, an unmarried-born child gets his or her legal hereditary, inheritance right and guardian right. The dispute on the issue has not found clear solution to answer all the debate among societies. This writing tries to explore the form of mediation which aims at making clear the implementation of unmarried-born child status regulation of which it can make constitutional regulation and Islamic law in line considering muslim society as the majority in Indonesia

Putusan Mahkamah Konstitusi (MK) yang mengabulkan uji materi UU perkawinan nomor 1/1974 pasal 43 (1) pada pertengahan Februari 2012 masih menyisakan polemik di masyarakat. Dalam pertimbangan hukumnya, MK menyatakan bahwa terlepas dari soal prosedur atau administrasi per kawinannya, anak yang dilahirkan harus mendapat perlindungan hukum sebab jika tidak demikian, maka yang dirugikan adalah anak yang dilahirkan di luar perkawinan. Dengan pertimbangan tersebut MK menegaskan adanya hubungan perdata antara anak yang lahir di luar nikah dengan ayah biologisnya bila dapat dibuktikan. Sebagai imbas dari munculnya pasal baru tersebut adalah kejelasan nasab, hak waris dan hak perwalian dari anak yang lahir di luar nikah. Hal tersebut menimbulkan makna implementasi yang berbeda di kalangan umat muslim khususnya. 
Menurut syari'at islam, nasab bukanlah ditentukan dari ada atau tidaknya bukti otentik baik secara teknologi maupun bukti lainnya melainkan dari sah tidaknya perkawinan antara seorang laki-laki dan perempuan. Pertentangan tersebut hingga kini belum menemui titik terang yang dapat menjawab gejolak yang muncul di masyarakat. Dibutuhkan kesatuan interpretasi yang bertujuan untuk memperjelas implementasi putusan MK tersebut sehingga antara aturan konstitusi dan aturan syari'ah dapat berjalan selaras dan seimbang mengingat masyarakat indonesia sebagian besar adalah muslim.

Keywords: pernikahan, UU Perkawinan 1/1974 pasal 43 ayat 1, anak sah, anak luar nikah

\section{Pendahuluan}

"Pengesahan Nikah Siri Melonjak 300 persen". Demikianlah bunyi salah satu headline di jawa pos pada hari senin, tanggal 26 Maret 2012. Fenomena tersebut muncul selaras dengan adanya pengumuman putusan Mahkamah Konstitusi (MK) tentang uji materi Pasal 43 ayat 1 UU nomor 1 Tahun 1974 tentang perkawinan yang beberapa pekan terakhir sarat diberitakan di berbagai media karena dianggap kontroversial oleh beberapa pihak (Jawa Pos, 26/03/2012).

Isbat nikah untuk pernikahan tidak sah atau tidak tercatat sebenarnya lebih ditujukan untuk perlindungan terhadap hak anak dan keturunan. Komisi perlindungan anak Indonesia (KPAI) mengungkapkan hampir 50 juta anak di Indonesia tidak memiliki akta kelahiran karena berbagai sebab yang salah satu diantaranya adalah karena pernikahan tidak sah atau perkawinan tidak tercatat atau kawin siri. Angka tersebut hampir separuh dari total jumlah anak dibawah 5 tahun yang ada di Indonesia. Karenanya, KPAI menyatakan sangat mengapresiasi putusan MK beberapa waktu lalu yang mengabulkan permohonan uji materi atas pasal anak di luar pernikahan sah dalam UU perkawinan.

Putusan MK yang mengabulkan uji materi UU perkawinan pada pertengahan Februari lalu memang masih menimbulkan polemik di kalangan ulama khususnya dan masyarakat umumnya. Sebagian ulama menganggap putusan itu baik dan bermanfaat karena dapat dijadikan dasar untuk melindungi nasib anak-anak utamanya anak yang lahir di luar pernikahan yang sah dari kemungkinan ditelantarkan oleh ayahnya, akan tetapi 
sebagian ulama yang lain berpendapat bahwa keputusan MK tersebut dapat memicu legalnya praktek perzinahan (Jawa Pos, 20/02/2012). Nasaruddin Umar dalam paparannya juga mempertanyakan adanya benturan antara aturan konstitusi dengan aturan syari'ah yang ada akibat munculnya putusan MK tersebut. Sebagaimana diketahui, dalam islam anak yang lahir di luar perkawinan yang sah hanya memiliki nasab dengan pihak ibu dan keluarga dari pihak ibu sedangkan putusan MK menyatakan anak luar nikah juga memiliki hubungan perdata dengan ayah biologisnya (Jawa Pos, 27/03/2012).

Imbas dari putusan MK tersebut memang sangat luas. Secara hukum, akan ada lagi hukum-hukum lanjutan yang terkait dengan diakuinya status anak yang lahir di luar nikah seperti hukum nasab, hukum waris dan perwalian dalam pernikahan. Oleh sebab itu, pendalaman makna dan pengkajian ulang dengan melibatkan berbagai pihak sehubungan dengan munculnya putusan uji materi oleh MK tersebut menjadi sangat penting, agar tidak ada kesalahpahaman implementasi atas munculnya putusan tersebut serta adanya keselarasan antara aturan konstitusi yang dibuat dan aturan syari'ah yang berlaku di Indonesia.

\section{Perkawinan dalam Aturan Konstitusi dan Syari’ah}

Nikah secara bahasa berarti berkumpul dan bersetubuh. Menurut istilah syari'at, nikah adalah akad yang mengandung kebolehan untuk bersetubuh dengan lafadz inkah atau tazwij (Sopyan, 2004). Definisi yang lebih lengkap dan sarat dengan makna filosofis tentang perkawinan tertuang dalam UU Perkawinan No.1 tahun 1974 pasal 1 yang berbunyi :

"Perkawinan ialah ikatan lahir batin antara seorang pria dengan seorang wanita sebagai suami istri dengan tujuan membentuk keluaga (rumah tangga) yang bahagia dan kekal berdasarkan Ketuhanan Yang Maha Esa”

Kompilasi Hukum Islam Pasal 4 menyebutkan Perkawinan adalah sah apabila dilakukan menurut hukum Islam, hal ini sesuai dengan pasal 2 ayat (1) Undang-undang No. 1 Tahun 1974 tentang Perkawinan yang menyebutkan "Perkawinan adalah sah apabila dilakukan menurut hukum masing-masing agama dan kepercayaannya itu". Adapun syarat dan rukun pernikahan menurut hukum islam adalah : 
1. Adanya calon suami dan calon istri yang akan melaksanakan pernikahan

2. Adanya wali nikah bagi calon pengantin perempuan

3. Adanya dua orang saksi

4. Adanya sighat akad nikah

5. Adanya mas kawin (mahar)

Dari lima rukun nikah itu, tak ada seorang ulama (dari empat mazhab) yang mengemukakan bahwa sebuah pernikahan harus dicatat. Tidak ditemukan dalil dalam Al-Qur'an maupun Hadits Sahih yang secara eksplisit mewajibkan adanya pencatatan nikah. Kendati demikian, pencatatan nikah atau perkawinan telah diamanatkan Pasal 2 ayat (2) UU No 1 Tahun 1974 tentang Perkawinan dengan tujuan untuk melindungi warga negara dalam membangun keluarga dan memberikan kepastian hukum terhadap hak suami, istri, dan anak-anaknya. Pencatatan nikah bertujuan untuk mewujudkan ketertiban perkawinan dalam masyarakat. Ini merupakan suatu upaya yang diatur melalui undang-undang untuk melindungi martabat dan kesucian pernikahan (Rofiq, 1995). Pencatatan nikah hanya sebuah kebutuhan administrasi negara, namun fungsinya sangat penting terutama bagi kaum hawa.

Di antara manfaat pernikahan adalah untuk menghindarkan teraniayanya pihak perempuan sebagai istri sebab dilindungi adanya status hukum yang jelas terhadap pernikahan yang diselenggarakan. Tidak sedikit perempuan dan anak-anak di Indonesia yang menjadi korban dari tidak tercatatnya suatu pernikahan walaupun pernikahan mereka telah sah secara agama (Sopyan, 2004).

UU No. 1 tahun 1974 menyebutkan :

Pasal 2 ayat 1 berbunyi "Perkawinan adalah sah apabila dilakukan menurut hukum masing-masing agama dan kepercayaannya itu".

Pasal 2 ayat 2 berbunyi "Tiap-tiap perkawinan dicatat menurut peraturan perundang-undangan yang berlaku”.

Begitu pula di dalam Pasal 5 Kompilasi Hukum Islam disebutkan:

1. Agar terjamin ketertiban perkawinan bagi masyarakat Islam setiap perkawinan harus dicatat.

2. Pencatatan perkawinan tersebut pada ayat (1), dilakukan oleh Pegawai Pencatat Nikah sebagaimana yang diatur 
dalam Undang-undang No.22 Tahun 1946, Undang-undang No. 32 Tahun 1954.

Pasal 2 ayat 2 dari UU 1/1974 bagi sebagian masyarakat menimbulkan ambiguitas bagi pemaknaan pasal 2 ayat $1 \mathrm{UU}$ 1/1974 sebab pencatatan yang dimaksud dalam pasal tersebut tidak ditegaskan apakah sekedar pencatatan secara administratif yang tidak berpengaruh terhadap sah atau tidaknya perkawinan yang telah dilangsungkan menurut agama dan kepercayaannya atau pencatatan tersebut berpengaruh terhadap sah atau tidaknya perkawinan yang telah dilakukan.

Berdasarkan tinjauan sosiologis tentang lembaga perkawinan dalam masyarakat, sahnya perkawinan menurut agama dan kepercayaan tertentu tidak dapat secara langsung menjamin terpenuhinya hak-hak keperdataan istri, suami dan anak-anak yang dilahirkan karena pelaksanaan norma agama dan adat di masyarakat diserahkan sepenuhnya kepada kesadaran individu yang bersangkutan. Hal inilah yang menyebabkan pernikahan siri yang dianggap sah secara agama Islam tetap harus sah secara hukum Negara melalui pengajuan pencatatan. Tanpa adanya pencatatan secara hukum Negara, maka anak-anak yang lahir dari perkawinan tersebut tidak dapat dibuktikan secara hukum merupakan anak sah dari ayahnya. Akibatnya, si anak hanya memiliki hubungan hukum dengan ibu yang melahirkannya. Hal ini dipertegas dalam pasal 43 ayat 1 UU perkawinan yang berbunyi : "Anak yang dilahirkan di luar perkawinan hanya mempunyai hubungan perdata dengan ibunya dan keluarga ibunya".

Menurut pemerintah, tujuan dari pemberlakuan pasal tersebut adalah untuk memberikan perlindungan dan kepastian hukum terhadap hubungan keperdataan antara anak dan ibunya serta keluarga ibunya sebab perkawinan yang tidak dicatatkan dapat diartikan bahwa tidak pernah terjadi pernikahan. Akibatnya anak yang lahir dikategorikan sebagai anak yang lahir di luar pernikahan yang sah. Ketentuan dalam pasal ini merupakan konsekuensi logis dari adanya pengaturan mengenai persyaratan dan prosedur perkawinan yang sah atau sebaliknya karena menjadi tidak logis apabila UU memastikan adanya hubungan hukum seorang anak yang lahir dari seorang perempuan dengan laki-laki yang tidak terikat perkawinan yang sah dengan perempuan tersebut. 


\section{Anak Sah dan Anak Luar Nikah}

Pentingnya menjelaskan nasab dan asal-usul kekerabatan telah ditegaskan oleh Allah SWT dalam Al-Qur'an surat Al-Ahzab ayat $4-5$ yang berbunyi :

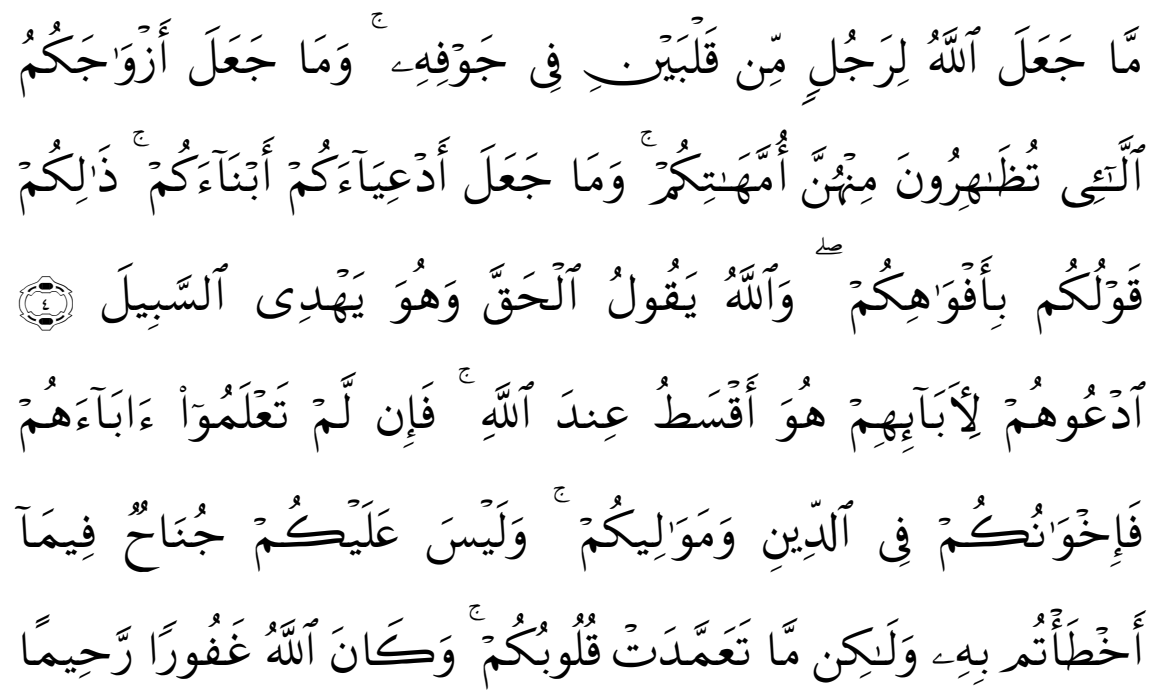

Artinya : Allah sekali-kali tidak menjadikan bagi seseorang dua buah hati dalam rongganya; dan Dia tidak menjadikan istri-istrimu yang kamu zhihar itu sebagai ibumu, dan Dia tidak menjadikan anak-anak angkatmu sebagai anak kandungmu (sendiri). yang demikian itu hanyalah perkataanmu dimulutmu saja. dan Allah mengatakan yang sebenarnya dan Dia menunjukkan jalan (yang benar). Panggilah mereka (anak-anak angkat itu) dengan (memakai) nama bapak-bapak mereka; Itulah yang lebih adil pada sisi Allah, dan jika kamu tidak mengetahui bapak-bapak mereka, Maka (panggilah mereka sebagai) saudara-saudaramu seagama dan maula-maulamu. dan tidak ada dosa atasmu terhadap apa yang kamu khilaf padanya, tetapi (yang ada dosanya) apa yang disengaja oleh hatimu. dan adalah Allah Maha Pengampun lagi Maha Penyayang (Q.S. Al-ahzab ayat 4-5).

Menurut Hukum Perkawinan Nasional Indonesia, status anak dibedakan menjadi dua yaitu anak sah dan anak luar nikah. Anak sah se- 
bagaimana yang dinyatakan UU Perkawinan Tahun 1974 adalah anak yang dilahirkan dalam atau sebagai akibat perkawinan yang sah. Sedangkan menurut Kompilasi Hukum Islam (KHI) pasal 99, anak sah adalah :

(a) anak yang lahir dalam atau sebagai akibat perkawinan yang sah

(b) Hasil pembuahan suami istri yang sah di luar rahim dan dilahirkan oleh istri tersebut.

Pengertian dari istilah anak luar nikah adalah anak yang dibuahi dan dilahirkan di luar pernikahan yang sah. Dalam peraturan perundangundangan Nasional yaitu UU No. 1 Tahun 1974 Pasal 43 ayat 1, dinyatakan bahwa "anak yang dilahirkan di luar perkawinan hanya mempunyai hubungan perdata dengan ibunya dan keluarga ibunya". Pasal inilah yang setelah uji materi berubah menjadi "anak yang dilahirkan di luar perkawinan mempunyai hubungan perdata dengan ibunya dan keluarga ibunya serta dengan laki-laki sebagai ayahnya yang dapat dibuktikan berdasarkan ilmu pengetahuan dan atau alat bukti lain menurut hukum mempunyai hubungan darah termasuk hubungan perdata dengan keluarga ayahnya" (Jawa Pos, 18/02/2012).

Putusan MK tersebut sangat bertentangan dan kontras dengan pasal 100 Kompilasi Hukum Islam (KHI) yang menyebutkan "anak yang lahir diluar perkawinan hanya mempunyai hubungan nasab dengan ibunya dan keluarga ibunya". Pasal 100 dalam Kompilasi Hukum Islam ini dibuat sebagai perwujudan hukum yang terdapat dalam al-qur'an dan al-hadits. Hadits yang menerangkan bahwa anak yang lahir di luar perkawinan atau sering disebut anak zina dinasabkan kepada ibunya diriwayatkan oleh Abu Dawud yang berbunyi "Nabi Muhammad SAW bersabda tentang anak hasil zina: "bagi keluarga ibunya...." (HR. Abu Dawud).

Hubungan kewarisan antara anak zina dengan lelaki yang mengakibatkan kelahirannya diterangkan dalam hadits berikut :

"Dari 'Amr Ibn Syuaib r.a, dari ayahnya, dari kakeknya, bahwa Rasulullah SAW bersabda: Setiap orang yang menzinai perempuan baik merdeka maupun budak, maka anaknya adalah anak hasil zina, tidak mewarisi dan tidak mewariskan" (HR. Turmudzi).

Majelis Ulama Indonesia (MUI) dalam fatwa MUI Nomor 11 tahun 2012 menegaskan bahwa dalam islam, anak terlahir dalam kondisi 
suci dan tidak membawa dosa turunan sekalipun ia terlahir sebagai hasil zina, sebagaimana firman Allah SWT dalam surat Al-An'am ayat 164 yang artinya :

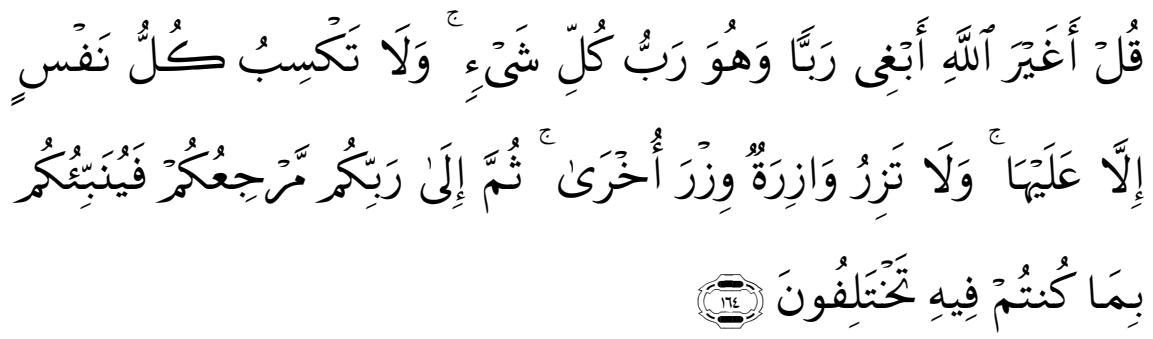

Artinya : Katakanlah: "Apakah aku akan mencari Tuhan selain Allah, Padahal Dia adalah Tuhan bagi segala sesuatu. dan tidaklah seorang membuat dosa melainkan kemudharatannya kembali kepada dirinya sendiri; dan seorang yang berdosa tidak akan memikul dosa orang lain. kemudian kepada Tuhanmulah kamu kembali, dan akan diberitakan-Nya kepadamu apa yang kamu perselisihkan." (Q.S Al-An'am ayat 164).

MUI dalam fatwanya juga menyadari realitas negatif yang berkembang di masyarakat bahwa anak hasil zina seringkali terlantar karena laki-laki yang menyebabkan kelahirannya tidak bertanggung jawab dan terdiskriminasi karena dalam akte kelahirannya hanya dinisbatkan kepada ibu. Kedua poin tersebut adalah pertimbangan yang digunakan majelis hakim dalam mengabulkan uji materi UU perkawinan No. 1 Tahun 1974 Pasal 43 ayat 1 . Akan tetapi, polemik yang kemudian muncul terutama di kalangan masyarakat muslim adalah tentang hubungan nasab, waris dan wali nikah anak luar nikah tersebut. Hal ini disebabkan dalam putusannya, MK menegaskan adanya hubungan perdata antara anak yang dihasilkan di luar pernikahan dengan ayahnya yang bisa dibuktikan dengan teknologiseperti test DNA. Kelemahan dari putusan ini adalah tidak dinyatakan bahwa maksud dari kata-kata anak hasil di luar pernikahan adalah anak hasil nikah siri saja atau yang juga hasil hubungan di luar pernikahan yang sah. Bahkan dalam beberapa media diberitakan bahwa pihak yang mengeluarkan putusan mengatakan bahwa yang dimaksud dengan di luar pernikahan adalah nikah siri atau anak hasil perzinaan, kumpul kebo, selingkuh dan lain sebagainya selama anak tersebut bisa dibuktikan hubungan darahnya melalui teknologi yang canggih (Hidayat, 2011). 
Pernyataan inilah yang memicu pertentangan antara Mahkamah Konstitusi dan masyarakat Indonesia yang mayoritas beragama Islam.

Pendapat jumhur mazhab fikih Hanafiyah, Malikiyah, Syafi'iyah dan Hanabilah menyatakan bahwa prinsip penetapan nasab adalah karena adanya hubungan pernikahan yang sah. Selain karena adanya pernikahan yang sah, maka tidak akan ada akibat hukum hubungan nasab, dan dengan demikian anak zina dinasabkan kepada ibunya. Pendapat yang sama disampaikan imam al-sayyid al-bakry dalam kitab "I'anatu At-Thalibin" Juz 2 halaman 128 yang berbunyi "Anak zina itu tidak dinasabkan kepada ayah, ia hanya dinasabkan kepada ibunya".

Pendapat yang sama disampaikan Imam Ibn Hazm dalam kitab AlMuhalla Juz 10 halaman 323 yang artinya sebagaimana berikut "Anak itu dinasabkan kepada ibunya jika ibunya berzina dan kemudian mengandung dan anak itu tidak dinasabkan kepada laki-laki”.

Ibnu Nujaim dalam kitab Al-bahr al-Raiq Syarh Kanz Ad-daqaiq menyatakan "anak hasil zina atau li'an hanya mendapatkan hak waris dari pihak ibu saja karena nasabnya dari pihak bapak telah terputus. Maka ia tidak mendapat hak waris dari pihak bapak. Sementara kejelasan nasabnya hanya melalui pihak ibu maka ia memiliki hak waris dari pihak ibu, saudara perempuan seibu dengan bagian tertentu. Demikian pula dengan ibu dan saudara perempuannya yang seibu, ia mendapatkan bagian tertentu, tidak dengan jalan lain”.

Dalam fatwanya, MUI memutuskan bahwa yang disebut anak zina adalah anak yang lahir sebagai akibat dari hubungan badan di luar pernikahan yang sah menurut ketentuan agama dan merupakan tindak pidana kejahatan. Anak hasil zina tidak mempunyai hubungan nasab, waris, wali nikah dan nafaqah dengan lelaki yang menyebabkan kelahirannya dan hanya mempunyai nasab dengan ibu dan keluarga ibunya. Menurut MUI, pemerintah berwenang menjatuhkan hukuman bagi lelaki yang mengakibatkan kelahiran anak dengan cara mencukupi kebutuhan hidup anak dan memberikan harta melalui wasiat wajibah setelah ia meninggal dengan maksud melindungi anak dan bukan untuk tujuan mensahkan hubungan nasab antara anak dengan lelaki yang di maksud.

Nurul Irfan dari UIN Syarif Hidayatullah berpendapat putusan MK tersebut memang mengarah ke pembagian harta ayah kepada anak di 
luar nikah. Tapi, pembagian harta tersebut tidak bisa diimplementasikan sebagai warisan menurut konsep dasar hukum Islam. Warisan menurut konsep dasar hukum Islam memiliki syarat seperti adanya nasab atau hubungan sah menurut pernikahan. Nasab sendiri adalah keturunan darah atau hubungan-hubungan kekerabatan di dalam Islam melalui pernikahan yang sah atau melalui pengakuan seorang laki-laki bahwa itu anaknya yang selanjutnya diikuti dengan adanya bukti-bukti DNA dan tes darah. Menurut Irfan, bila mau disinkronisasi dengan konsep dasar hukum Islam maka lebih tepat bila kewajiban menafkahi tidak disebut sebagai waris, jadi anak tersebut boleh memperoleh haknya tetapi bukan nama waris, misalnya, hibah, sedekah dan lain-lain.

Syarif Zubaidah, dosen Fakultas Ilmu Agama Islam (FIAI) UII Yogyakarta dalam Seminar Regional 'Menyikapi Putusan Mahkamah Konstitusi Nomor 46/PUU-IX/2011 tentang Tanggung Jawab Ayah terhadap Anak di luar nikah' menyatakan tes DNA tidak bisa menentukan status anak untuk mempunyai nasab dengan laki-laki yang menghamili perempuan yang menyebabkan kelahiran anak. Namun hanya akad nikah yang bisa menentukan hubungan nasab anak dengan ayah biologisnya. Pengakuan adanya hubungan nasab antara anak dan ayah akan menimbulkan empat hak. Yaitu, hak pengakuan terhadap anak sebagai ayah, hak ayah untuk bertanggung jawab terhadap anak, hak untuk mewarisi, dan hak ayah untuk menjadi wali bagi anak perempuan.

Menurut hukum Islam nikah itu sah jika memenuhi empat persyaratan yaitu shihhah, in'iqat, nafadh, luzum. Karena itu, tidak ada ketentuan bahwa ayah mempunyak tanggung jawab terhadap anak di luar pernikahan. Sebab penyebutan ayah hanya berlaku bagi anak sah, yaitu anak yang dilahirkan sebagai akibat perkawinan yang sah (Republika. co.id).

\section{Mahkamah Konstitusi dan Kewenangannya}

Memerangi ketidakadilan sosial sepanjang sejarah kemanusiaan selalu menjadi topik dan tema menarik, dan tetap akan menjadi tema penting dalam setiap pemikiran dan konsepsi tentang kemasyarakatan di masa mendatang (Fakih, 1996). Tidak sedikit yang memandang rendah terhadap mereka yang berjuang memerangi ketidakadilan sosial dan meragukan pemikiran, sikap dan tindakan yang dilakukan untuk mencapai 
hasil yang diharapan. Demikian pula keragu-raguan yang tertuju pada Mahkamah Konstitusi (MK).

Keraguan atas kewenangan Mahkamah Konstitusi atau MK dalam memutuskan uji materi terhadap suatu UU bagi sebagian kalangan yang awam tentang hukum memang sempat muncul sehubungan dengan dikeluarkannya putusan uji materi UU Perkawinan tersebut. Pertanyaan seputar apa Mahkamah Konstitusi serta apa saja tugas dan kewenangannya juga beberapa kali dipertanyakan dan diulas dalam beberapa media baik cetak maupun elektronik.

Mahkamah Konstitusi adalah lembaga tinggi negara dalam sistem ketatanegaraan Indonesia yang merupakan pemegang kekuasaan kehakiman bersama-sama dengan Mahkamah Agung. Pasal 24 ayat 2 Undang-Undang Dasar Negara Republik Indonesia Tahun 1945 (UUD 1945) menyatakan, kekuasaan kehakiman dilakukan oleh sebuah Mahkamah Agung dan badan peradilan yang berada di bawahnya dalam lingkungan peradilan umum, lingkungan peradilan agama, lingkungan peradilan militer, lingkungan peradilan tata usaha negara, dan oleh sebuah Mahkamah Konstitusi (MK) (Sofyan, 2012).

Berdasarkan ketentuan tersebut, Mahkamah Konstitusi merupakan salah satu pelaku kekuasaan kehakiman selain Mahkamah Agung. Kekuasaan kehakiman merupakan kekuasaan yang merdeka untuk menyelenggarakan peradilan guna menegakkan hukum dan keadilan. Dengan demikian, Mahkamah Konstitusi adalah suatu lembaga peradilan, sebagai cabang kekuasaan yudikatif, yang mengadili perkara-perkara tertentu yang menjadi kewenangannya berdasarkan ketentuan UUD 1945 (Sofyan, 2012).

Berdasarkan pasal24C ayat 1 UUD 1945 yang ditegaskankembali dalam pasal 10 ayat 1 huruf a sampai dengan d UU 24/2003,kewenangan Mahkamah Konstitusi adalah sebagai berikut :

1. menguji undang-undang terhadap UUD NRI Th.1945;

2. memutus sengketa kewenangan lembaga Negara yang kewenangannya diberikan oleh UUD NRI Th.1945;

3. memutus pembubaran partai politik;

4. memutus perselisihan tentang hasil pemilihan umum. 
Mengacu pada poin di atas, terkait dengan kontroversialnya putusan MK tentang perkawinan yang muncul beberapa pekan terakhir, dapat dijelaskan bahwa Mahkamah Konstitusi memiliki kewenangan dalam menguji undang-undang perkawinan tersebut dan memiliki kewenangan mengabulkan atau tidak mengabulkan permohonan uji materi atas UU tersebut. Menurut Helza Nova Lita dalam hukumonline.com, kewenangan MK sesuai dengan UUD 1945 dan UU hanya melakukan judicial review atau uji materi terhadap pasal yang diajukan pemohon untuk diuji. Akan tetapi, kewenangan mengabulkan uji materi tersebut bukan disertai kewenangan membuat aturan UU atau hukum baru karena itu kewenangan legislatif.

Putusan MK terhadap uji materi UU perkawinan merupakan hasil uji materi terhadap pengajuan permohonan uji materi artis Machicha Mochtar yang meliputi pasal-pasal berikut ini :

\begin{tabular}{|l|l||}
\hline \multicolumn{1}{|c|}{ UUD 1945 } & \multicolumn{1}{|c||}{$\begin{array}{c}\text { UU No 1 Th 1974 tentang } \\
\text { Perkawinan }\end{array}$} \\
\hline $\begin{array}{l}\text { Pasal 28 B ayat 1 } \\
\text { "Setiap orang berhak membentuk } \\
\text { keluarga dan melanjutkan keturu- } \\
\text { nan melalui perkawinan yang sah “ }\end{array}$ & $\begin{array}{l}\text { Pasal 2 ayat 2 } \\
\text { "Tiap-tiap perkawinan dicatat me- } \\
\text { nang berlaku “ }\end{array}$ \\
\hline $\begin{array}{l}\text { Pasal 28 B ayat 2 } \\
\text { " Setiap anak berhak atas kelang- } \\
\text { sungan hidup, tumbuh, dan ber- } \\
\text { kembang serta berhak atas perlin- } \\
\text { dungan dari kekerasan dan dis- } \\
\text { kriminasi " }\end{array}$ & $\begin{array}{l}\text { Pasal } 43 \text { ayat 1 } \\
\text { kawak yang dilahirkan di luar per- } \\
\text { bungan perdata dengan ibunya dan } \\
\text { keluarga ibunya " }\end{array}$ \\
\hline $\begin{array}{l}\text { Pasal 28 D ayat 1 } \\
\text { “ Setiap orang berhak atas peng- } \\
\text { akuan, jaminan, perlindungan, dan } \\
\text { kepastian hukum yang adil serta } \\
\text { perlakuan yang sama di hadapan } \\
\text { hukum “ }\end{array}$ & \\
\hline
\end{tabular}

Dalam amar putusannya, Mahkamah Konstitusi memberikan putusan mengabulkan sebagian permohonan para pemohon. Pasal 2 ayat 2 UU Perkawinan tidak dikabulkan sebab perkawinan yang dicatatkan adalah 
untuk mencapai tertib administrasi. Pencatatan perkawinan bukanlah faktor yang menetukan sah tidaknya perkawinan. Pencatatan secara administratif yang dilakukan Negara dimaksudkan agar perkawinan, sebagai perbuatan hukum penting dalam kehidupan yang dilakukan oleh yang bersangkutan, yang berimplikasi terjadinya akibat hukum yang sangat luas, di kemudian hari dapat dibuktikan dengan bukti yang sempurna dengan suatu akta otentik, sehingga perlindungan dan pelayanan oleh Negara terkait dengan hak-hak yang timbul dari suatu perkawinan dapat terselenggara secara tertib dan efisien. Artinya, dengan dimilikinya bukti otentik akta perkawinan, hak-hak yang timbul sebagai akibat perkawinan dapat terlindungi dan terlayani dengan baik, karena tidak diperlukan proses pembuktian yang memakan waktu, uang, tenaga, dan pikiran yang lebih banyak, seperti pembuktian mengenai asal-usul anak dalam pasal 55 UU perkawinan yang mengatur bahwa bila asal-usul anak tidak dapat dibuktikan dengan akta otentik maka mengenai hal itu akan ditetapkan dengan putusan pengadilan yang berwenang. Pembuktian yang demikian pasti tidak lebih efektif dan efisien bila dibandingkan adanya akta otentik sebagai bukti (Putusan MK Nomor 46/PUU-VIII/2010).

Selanjutnya, MK menegaskan bahwa faktor yang menentukan sahnya perkawinan adalah syarat-syarat yang ditentukan oleh agama dari masing-masing calon mempelai. Pasal 43 ayat 1 UU Perkawinan dikabulkan karena hubungan anak dengan seorang laki-laki sebagai bapak tidak semata-mata karena adanya ikatan perkawinan, akan tetapi dapat juga didasarkan pada pembuktian adanya hubungan darah antara anak dengan laki-laki tersebut sebagai bapak. Dengan demikian, terlepas dari soal prosedur/administrasi perkawinannya, anak yang dilahirkan harus mendapat perlindungan hukum. Jika tidak demikian, maka yang dirugikan adalah anak yang dilahirkan di luar perkawinan, padahal anak tersebut tidak berdosa karena kelahirannya di luar kehendaknya (Putusan MK Nomor 46/ PUU-VIII/2010).

\section{Penutup}

Sebagaimana yang telah diulas pada paragraf sebelumnya, bahwa dalam ayat revisi yang disampaikan Mahkamah Konstitusi tentang uji materi UU Perkawinan No. 1 Tahun 1974 Pasal 43 ayat 1 terdapat beberapa kalimat yang memunculkan ambiguitas makna dan multitafsir 
terhadap implementasi putusan tersebut. Kalimat yang dapat memicu ambiguitas pemahaman adalah konteks "anak di luar perkawinan" dan "hak perdata dari ayahnya". Menurut UU perkawinan, anak yang lahir di luar perkawinan dapat dimaknai anak yang lahir dari nikah siri yang tidak dicatatkan. Sejatinya, kedua kalimat tersebut memiliki koherensi yang kuat dimana hak perdata dari seorang ayah hanya dapat diterima oleh anak sah atau anak yang lahir sebagai akibat adanya perkawinan yang sah dalam perspektif agama islam, bukan anak yang hasil tes DNA-nya sama dengan laki-laki yang menyebabkan kelahiran anak. Penambahan penjelasan tentang anak di luar perkawinan pada UU yang diumumkan sebagai hasil uji materi dapat menjadi salah satu solusi dalam menjembatani polemik yang berkembang diantara kaum muslim umumnya, MUI dan MK. Tentu saja bila dipersepsikan dalam konteks islam, maksud dari anak di luar perkawinan adalah anak yang lahir dari perkawinan siri yang tidak tercatat atau belum dicatatkan. Dengan demikian redaksi "hak perdata dari ayahnya" tetap dapat dilekatkan.

Terlepas dari polemik yang terjadi, upaya MK mengentaskan hak ataupun status anak yang lahir di luar nikah adalah hal yang patut didukung, selama tidak melanggar syari'ah yang ada. Untuk itu, pemerintah diharapkan membuat sinkronisasi hukum dan peraturan perundangundangan yang berkaitan dengan perkawinan menurut agama dan kepercayaan, sehingga tidak menimbulkan pendapat atau opini yang tumpang tindih yang menimbulkan banyak masalah baru dan diharapkan penegakan hukum serta rasa keadilan di masyarakat dapat terwujud.

\section{DAFTAR PUSTAKA}

Fakih, M. DR. 1996. Analisis Gender dan Transformasi Sosial. Pustaka Pelajar. Yogyakarta.

Fatwa Majelis Ulama Indonesia Nomor 11 Tahun 2012 tentang Kedudukan Anak Hasil Zina dan Perlakuan Terhadapnya.

Hidayat, R. 2012. Status Anak di Luar Nikah Menurut Hukum Perkawinan Nasional dan Hukum Islam dalam www.negarahukum.com.

Jawa Pos. Sabtu, 18/02/2012. MK Akui Anak Hubungan Gelap.

Jawa Pos. Selasa, 27/03/2012. Kemenag Bakal Mediasi MK-MUI : Terkait 
Dualisme Status Anak Di Luar Nikah.

Jawa Pos. Senin, 20/02/2012. MUI Condong Hanya yang Nikah Siri.

Jawa Pos. Senin, 26/03/2012. Pengesahan Nikah Siri Melonjak 300 Persen.

Putusan Mahkamah Konstitusi Nomor 46/PUU-VIII/2010.

Ropiq, A. 1995. Hukum Islam di Indonesia. Rajawali Press. Jakarta

Sofyan, S. 2012. Putusan Mahkamah Konstitusi tentang Status Anak Luar Kawin dalam www.jimlyschool.com

Sopyan, Y. 2004. Pernikahan. Dalam Buku "Relasi Suami Istri Dalam Islam”. UIN Syarif Hidayatullah Press. Jakarta.

www.Hukumonline.com

www.Republika.co.id 